\title{
The Impact of Earnings Quality on the Cost of Equity: Evidence from Privatized Firms
}

\author{
Hamdi Ben-Nasr ${ }^{1} \&$ Abdullah Mohammed Al-Dakheel ${ }^{2}$ \\ ${ }^{1}$ Finance Department, College of Business Administration, King Saud University, Riyadh, Saudi Arabia \\ ${ }^{2}$ MSF Program, College of Business Administration, King Saud University, Riyadh, Saudi Arabia \\ Correspondence: Hamdi Ben-Nasr, Finance Department, College of Business Administration, King Saud University, \\ Riyadh, 71115, 11587, Saudi Arabia. Tel: 966-54-704-4326. E-mail: hbennasr@ksu.edu.sa
}

Received: October 26, 2014

Accepted: November 22, 2014

Online Published: December 18, 2014

doi:10.5430/ijfr.v6n1p68

URL: http://dx.doi.org/10.5430/ijfr.v6n1p68

\begin{abstract}
In this paper, we examine whether earnings quality affects cost of equity in privatized firms. Using a multinational sample of firms privatized in developing and industrialized countries, we find strong, robust evidence that the cost of equity is positively related to the absolute value of abnormal accruals. This finding suggests that firms with lower earnings quality are penalized with a higher cost of equity.
\end{abstract}

Keywords: earnings quality, abnormal accruals, cost of equity, privatization

\section{Introduction}

The economic outcomes of the quality of accounting information have recently drawn the interest of numerous scholars. In particular, several researchers have examined the impact of earnings quality on the cost of equity capital. For example, Bhattacharya, Daouk, and Welker (2003) examine the impact of earnings opacity as measured by earnings aggressiveness, loss avoidance, and earnings smoothing on cost of equity capital, around the world. In the same vein, Francis, La Fond, Olsson, and Schipper (2004) examine the impact of seven earnings attributes (accrual quality, earnings persistence, predictability, smoothness, value relevance, timeliness and conservatism) on the cost of equity capital in the US context. Recently, Bhattacharya, Ecker, Olsson and Schipper (2012) show that: earnings quality as measured by (i) accruals quality, (ii) abnormal accruals, and (iii) a measure that combines accruals quality, absolute abnormal accruals, and earnings variability affects directly the cost of equity capital. They also show that earnings quality also indirectly affects cost of equity capital through information asymmetry as measured by the probability of Informed trading (PIN). Similarly, Barth, Konchitchki, and Landsman (2013) examine the relation between the cost of equity capital and a new measure of earnings quality, namely the extent to which earnings and changes in earnings vary contemporaneously with stock returns.

In this paper, we extend the aforementioned studies by examining the impact of earnings quality on the cost of equity capital in the specific context of privatized firms. This context is an ideal environment where we can examine the impact of earnings quality on the cost of equity capital. In fact, the drastic change in the ownership structure of former state-owned enterprises due to privatization, which is accompanied by severe information asymmetry problems (Denis and McConnell, 2003; Dyck, 2001), provides us with a unique opportunity to investigate how earnings quality may affect the cost of equity capital. In addition, privatized firms are also characterized by the presence of the government as a residual shareholder, even several years after privatization (e.g., Bortolotti and Faccio, 2009; Boubakri et al., 2011). Several studies show that firms with partial state ownership have easier access to government funds and an implicit guarantee of government bailout in case of distress. Similarly, firms with political ties are shown to have relatively easy access to debt financing. For example, Faccio et al. (2006) find that politically connected firms are more likely to be bailed out than their non-politically connected peers. In the same vein, Charumilind et al. (2006) show that Thai firms with connections to banks and politicians obtained more long-term loans and needed less collateral during the period preceding the Asian financial crisis of 1997 compared to firms without such connections. Similarly, firms with political ties are shown to have relatively easy access to debt financing. Chaney, Faccio, and Parsley (2011) report evidence suggesting that politically connected firms with a lower earnings quality are not penalized with a higher cost of debt. In contrast, they find that the cost of debt of politically connected firms is lower than the cost of debt of comparable non-politically connected peers. Given this 
discussion, the quality of accounting information in the context of privatized firms could be less important for privatized firms. With this in mind, we investigate whether the positive relation found for private firms mainly in the US context is also valid for privatized firms around the world.

Using a multinational sample privatized firms from 32 countries (Industrialized and developing countries) covering the period between 1987 and 2006, we find strong and robust evidence that lower absolute value of discretionary abnormal accruals (i.e., higher earnings quality) is associated with lower cost of equity, suggesting that higher earnings quality is associated with high precise information about the cash flows of the firm, which reduces the amount of information risk (e.g., Lambert et al., 2008), leading to a lower cost of equity. Our finding is also consistent with the conjecture that higher earnings quality is associated with a lower cost of equity capital since it is accompanied with lower information asymmetry and lower systematic risk, respectively.

Our paper has two main contributions to the literature. First, we contribute to the literature on the cost of equity capital (e.g., Hail and Leuz, 2006, 2009; Ben-Nasr, Boubakri, and Cosset, 2012; Hwang, Lee, Lim and Park, 2013; Brushwood, Dhaliwal, Fairhurst, Serfling, 2014; Dhaliwal, Judd, Serfling and Shaikh, 2014; Mishra, 2014, among others), by emphasizing the role of earnings quality in determining the cost of equity financing. Second, we extend to the literature on the economic outcomes of earnings quality (e.g., Francis et al., 2004; Bhattacharya et al., 2012; Barth et al., 2013, among others) by using a multinational sample of firms from developing and developed countries and the higher-power setting of newly privatized firms (NPFs).

The rest of the paper proceeds as follows. Section 2 develops our testable hypothesis. Section 3 describes the sample, the data and the construction of the test variables. Section 4 reports the results of our empirical analysis and section 5 summarizes and concludes.

\section{Hypothesis Development}

Earnings quality may directly the cost of equity. In fact, high earnings quality represents precise information about the cash flows of the firm, which reduces the amount of information risk (e.g., Lambert et al., 2008), hence leads to a lower cost of equity. Consistent with this point of view, Bhattacharya et al. (2012) show that higher earnings quality is associated with lower cost of equity in the US context. In the same vein, Barth et al. (2013) show a negative relation between the extent to which earnings and changes in earnings vary contemporaneously with stock returns and the cost of equity.

Earnings quality may indirectly affect the cost of equity through information asymmetry and systematic risk. Extensive theoretical and empirical literature shows that high quality accounting information reduces information asymmetry. For example, Bhattacharya et al. (2013) measure information asymmetry by the adverse selection component of bid-ask spread (the price impact). They report evidence suggesting that earnings quality is associated with lower adverse selection component of bid-ask spread, hence higher liquidity. Higher liquidity leads to a lower cost of equity (Diamond, Douglas, and Verrecchia, 1991)). In the same vein, Bhattacharya et al. (2012) show that higher earnings quality is associated with lower PIN, which also leads to a lower cost of equity (e.g., Easely, Hvidkjaer and O Hara, 2002). Additionally, prior research shows that higher earnings quality is associated with lower systematic risk. For example, Francis, LaFond, Olsson and Schipper (2005) show that higher accruals quality is associated with lower beta, hence lower cost of equity capital.

In light of this discussion, our testable hypothesis states:

Hypothesis: Ceteris paribus, earnings quality and cost of equity capital are positively related.

\section{Research Design}

\subsection{Earnings Quality Proxy}

To investigate the impact of earnings quality on the cost of equity, we construct a sample of 161 privatized firms from 32 countries over the period from 1987 and 2006. To do so we begin with Ben-Nasr et al.'s (2012) sample firms. We then update this sample using several data sources including The World Bank's privatization database for developing countries, the Privatization Barometer for OECD countries, and Megginson's (2003) updated list of privatized firms in developed and developing countries. We obtain stock price data from Datastream, analyst forecast data from I/B/E/S, and financial data form Worldscope. The Appendix defines the variables used in our empirical analysis and their sources.

Table 1 provides some descriptive statistics about the 161 firms from 32 countries used in this study. The 161 firms are diversified across development levels. Specifically, $37.27 \%$ of the sample firms are located in developing countries, while the remaining $62.73 \%$ are located in developed countries. Interestingly, this diversification involves 
countries with different legal, political, and institutional environments, allowing us to investigate what impact these cross-country differences have on the cost of equity. As reported in Table 1, our sample is also diversified across industries, with $22.36 \%$ in the utility sector, $17.39 \%$ in the transportation sector, $13.04 \%$ in the financial sector, $14.29 \%$ in the basic industries sector and $8.07 \%$ in the consumer durables sectors. Furthermore, $58.39 \%$ of our sample's privatization transactions occurred in the 1990s.

Table 1. Description of the sample of privatized firms

\begin{tabular}{|c|c|c|c|c|c|}
\hline \multicolumn{3}{|c|}{ By year } & \multicolumn{3}{|c|}{ By industry } \\
\hline Year & Number & Percentage & Industry & Number & Percentage \\
\hline 1987 & 2 & 1.24 & Basic industries & 23 & 14.29 \\
\hline 1989 & 1 & 0.62 & Capital goods & 8 & 4.97 \\
\hline 1990 & 4 & 2.48 & Construction & 5 & 3.11 \\
\hline 1991 & 2 & 1.24 & Consumer durables & 13 & 8.07 \\
\hline 1992 & 4 & 2.48 & Finance/real estate & 21 & 13.04 \\
\hline 1993 & 2 & 1.24 & Food/tobacco & 7 & 4.35 \\
\hline 1994 & 9 & 5.59 & Leisure & 6 & 3.73 \\
\hline 1995 & 12 & 7.45 & Petroleum & 8 & 4.97 \\
\hline 1996 & 17 & 10.56 & Services & 3 & 1.86 \\
\hline 1997 & 14 & 8.70 & Textiles/trade & 3 & 1.86 \\
\hline 1998 & 17 & 10.56 & Transportation & 28 & 17.39 \\
\hline 1999 & 13 & 8.07 & Utilities & 36 & 22.36 \\
\hline 2000 & 13 & 8.07 & Total & 161 & 100 \\
\hline 2001 & 9 & 5.59 & & & \\
\hline 2002 & 6 & 3.73 & By re & ion & \\
\hline 2003 & 6 & 3.73 & Region (countries) & Number & Percentage \\
\hline 2004 & 14 & 8.70 & Africa and the Middle East (3) & 13 & 8.07 \\
\hline 2005 & 5 & 3.11 & East and South Asia and the Pacific (10) & 46 & 28.57 \\
\hline 2006 & 11 & 6.83 & Latin America and the Caribbean (2) & 3 & 1.86 \\
\hline \multirow[t]{7}{*}{ Total } & 161 & 100 & Europe and Central Asia (17) & 99 & 61.49 \\
\hline & & & Total (32) & 161 & 100.00 \\
\hline & & & \multicolumn{3}{|c|}{ By development level } \\
\hline & & & Category (countries) & Number & Percentage \\
\hline & & & Industialized countries (17) & 101 & 62.73 \\
\hline & & & Developing countries (15) & 60 & 37.27 \\
\hline & & & Total (32) & 161 & 100.00 \\
\hline
\end{tabular}

Notes: This table provides some descriptive statistics for the sample of 161 privatized firms used to investigate the Impact of earnings quality on the cost of equity in the context of privatized firms.

\subsection{Earnings Quality Proxy}

We use Dechow and Dichev's (2002) measure of abnormal accruals, as modified by Ball and Shivakumar (2005) to include asymmetrically timely loss recognition. Moreover, for the sake of parsimony, we use current abnormal accruals, in line with Degeorge et al. (2013). We estimate the following piecewise non-linear abnormal accruals model: 


$$
\frac{C A C_{i t}}{T A_{i t}}=\theta_{0}+\theta_{1} \frac{C F O_{i t-1}}{T A_{i t}}+\theta_{2} \frac{C F O_{i t}}{T A_{i t}}+\theta_{3} \frac{C F O_{i t+1}}{T A_{i t}}+\theta_{4} D C F O_{i t}+\theta_{5} D C F O_{i t} * \frac{C F O_{i t}}{T A_{i t}}+\varepsilon_{i t}
$$

where:

$C A C_{i t}=$ firm $i$ 's current accruals in year $t=\left(\Delta C A_{i t}-\Delta C L_{i t}-\Delta C A S H_{i t}+\triangle S T D E B T_{i t}\right)$;

$\Delta C A_{i t}=$ firm $i$ 's change in current assets between year $t-1$ and year $t$;

$\Delta C L_{i t}=$ firm $i^{\prime}$ s change in current in current liabilities between year $t-1$ and year $t$;

$\triangle C A S H_{i t}=$ firm $i$ 's change in cash and equivalents between year $t-1$ and year $t$;

$\triangle S T D E B T_{i t}=$ firm $i$ 's change in short and current long-term debt between year $t-1$ and year $t$;

$T A_{i t}=$ firm $i$ 's average total assets in year $t$ and $t-1$;

$C F O_{i t}=$ firm $i$ 's cash flows from operations in year $t=N I B E_{i t}-C A C_{i t}$;

$N I B E_{i t}=$ firm $i$ 's net income before extraordinary items in year $t$;

$C F O_{i t-1}=$ firm $i$ 's cash flows from operations in year $t-1$;

$C F O_{i t+1}=$ firm $i^{\prime}$ s cash flows from operations in year $t+1$;

$D C F O_{i t}=$ one if $\frac{C F O_{i t}}{T A_{i t}}-\frac{C F O_{i t-1}}{T A_{i t-1}}<0$, and zero otherwise.

The absolute value of the residuals resulting from equation (1), $\left|A A \_B A L L\right|$, is our proxy of earnings quality. Table 2 reports descriptive statistics for $\left|A A_{-} B A L L\right|$. As we can observe, the average (median) of $\left|A A \_B A L L\right|$ is $0.056(0.033)$, which is comparable to value reported by recent studies using this proxy of earnings quality (e., Ben-Nasr et al., 2014).

\subsection{Implied Cost of Equity Models}

We use estimates of the implied cost of equity based on the four following models:

3.3.1 Claus and Thomas (2001 CT)

$$
P_{t}=B_{t}+\sum_{i=1}^{5} \frac{\text { FEPS }_{t+i}-R_{C T} B_{t+i-1}}{\left(1+R_{C T}\right)^{i}}+\frac{\left[F E P S_{t+5}-R_{C T} B_{t+4}\right]\left(1+g_{l t}\right)}{\left(R_{C T}-g_{l t}\right)\left(1+R_{C T}\right)^{5}}
$$

where

$P_{t}=$ Market price of a firm's stock at time $t$.

$B_{t}=$ Book value per share at the beginning of the fiscal year.

$F E P S_{t+i}=$ Mean forecasted earnings per share from $\mathrm{I} / \mathrm{B} / \mathrm{E} / \mathrm{S}$ or implied EPS forecasts for year $t+i$.

$g_{l t}=$ The long-term abnormal earnings growth rate, calculated using the annualized yearly median of a country specific one-year-ahead realised monthly inflation rates.

$R_{C T}=$ The implied cost of equity derived from each of the four different models.

In this model the price is a function of the future forecasted earnings per share, the book value per share and the asymptotic long term growth rate. Claus and Thomas (2001) implement the model using the I/B/E/S forecasted earnings per share for the next five years. If the forecasts for earnings per share, $F E P S_{t+i}$, are not available in 
$\mathrm{I} / \mathrm{B} / \mathrm{E} / \mathrm{S}$ for the years $t+3, t+4$ and $t+5, F E P S_{t+i}=F E P S_{t+i-1}(1+L T G) . \quad L T G$ is the consensus long term growth rate form $\mathrm{I} / \mathrm{B} / \mathrm{E} / \mathrm{S}$ or the percentage change in forecasted earnings between year $t+2$ and year $t+3$. The future book values are estimated by assuming the clean surplus relation i.e., $B_{t+i}=B_{t+i-1}+F E P S_{t+i}-D P S_{t+i}$. The future dividend, $D P S_{t+i}$, is estimated by multiplying $F E P S_{t+i}$ by POUT. POUT is the firm's dividend payout ratio at time $t$ if available and $50 \%$ if not, as in Claus and Thomas (2001). $g_{l t}$ constitutes a lower bound for the cost of equity estimates.

3.3.2 Gebhardt, Lee and Swaminathan (2001 GLS)

$$
P_{t}=B_{t}+\sum_{i=1}^{T} \frac{\left(F R O E_{t+i}-R_{G L S}\right) B_{t+i-1}}{\left(1+R_{G L S}\right)^{i}}+\frac{\left(F R O E_{t+T+1}-R_{G L S}\right) B_{t+T}}{\left(1+R_{G L S}\right)^{T} R_{G L S}}
$$

For the years $t+1$ to $t+3, F R O E_{t+i}$ is equal to $F E P S_{t+i} / B_{t+i-1}$. After the forecast period of three years, $F R O E_{t+i}$ is derived by linear interpolation to the industry-median ROE. Average ROEs are computed in a given year and country for each of the 12 industry classifications of Campbell (1996). Negative industry median ROEs are replaced by country-year medians. The abnormal earnings at year $t+12$ are then assumed to remain constant afterwards. Future book values are estimated by assuming clean surplus. The future dividend, $D P S_{t+i}$, is estimated as FEPS $_{t+i}$ multiplied by POUT. We assume that $T=12$.

3.3.3 Ohlson and Juettner-Nauroth (OJ 2005)

$$
P_{t}=\left(F E P S_{t+1} / R_{O J}\right) \cdot\left(g_{s t}+R_{O J} \cdot D P S_{t+1} / F E P S_{t+1}-g_{l t}\right) /\left(R_{O J}-g_{l t}\right)
$$

where $g_{s t}=\left(F E P S_{t+2}-F E P S_{t+1}\right) / F E P S_{t+1}$.

This model is derived from the abnormal earnings valuation model developed by Ohlson and Juettner-Nauroth (2005). It uses one-year-ahead and two-years-ahead earnings per share, the future dividend per share and a proxy of the long term growth rate. The future dividend, $D P S_{t+i}$, is estimated as $F E P S_{t+i}$ multiplied by POUT . The asymptotic long term growth rate, $g_{l t}$, is calculated using the annualized yearly median of a country specific one-year-ahead realised monthly inflation rates. $g_{l t}$ constitutes a lower bound for the cost of equity estimates.

3.3.4 Easton (ES 2004)

$$
P_{t}=\frac{F E P S_{t+2}-F E P S_{t+1}+R_{E S} D P S_{t+1}}{R_{E S}^{2}}
$$

To implement the model, Easton (2004) uses the one-year ahead and two-years ahead forecasted earnings per share reported in $\mathrm{I} / \mathrm{B} / \mathrm{E} / \mathrm{S}$. The future dividend, $D P S_{t+i}$, is estimated by multiplying $F E P S_{t+i}$ by POUT. This model requires a positive change in forecasted earnings per share to yield a numerical solution.

Since the literature shows no strong consensus on which of the models most accurately estimates the cost of equity, we follow Dhaliwal et al. (2006) and Hail and Leuz (2006) and use the average of implied estimates from the four models as our estimate of the cost of equity $\left(R_{A V G}\right)$. Table 2 reports descriptive statistics for $R_{A V G}$. The average (median) value for $R_{A V G}$ is equal to $0.008(0.109)$.

Table 2. Descriptive statistics for the explanatory variables

\begin{tabular}{llllll}
\hline Variable & Mean & Median & $\begin{array}{l}\text { Standard } \\
\text { Deviation }\end{array}$ & Min & Max \\
\hline$R A V G$ & 0.008 & 0.109 & 0.101 & 0.051 & 0.517 \\
$\left|A A_{-} B A L L\right|$ & 0.056 & 0.033 & 0.089 & 0.000 & 0.709 \\
SIZE & 10.532 & 15.105 & 14.958 & 1.865 & 19.412
\end{tabular}




$\begin{array}{llllll}\text { TIME } & -9.000 & 1.072 & 1.000 & 1.380 & 7.000 \\ \text { LEVERAGE } & 0.000 & 0.412 & 0.417 & 0.275 & 2.651 \\ \text { MARKET TO BOOK } & 0.200 & 2.727 & 1.880 & 2.924 & 27.280 \\ \text { GROWTH_RATE } & -0.892 & 0.157 & 0.115 & 0.578 & 10.057 \\ \text { INFL } & 0.000 & 0.036 & 0.027 & 0.035 & 0.231 \\ \text { DISCREQ } & 0.250 & 0.608 & 0.670 & 0.192 & 1.000 \\ \text { ANALYST_COV } & 5.056 & 0.860 & 13.660 & 0.020 & 85.720 \\ \text { ANTISELF } & 0.160 & 0.448 & 0.380 & 0.218 & 1.000\end{array}$

This table presents descriptive statistics for the regression variables used in our multivariate analysis to examine the impact of state ownership on earnings quality for a sample of 161 privatized firms from 32 countries. Descriptions and data sources for the explanatory variables are outlined in the Appendix.

\section{Empirical Analysis}

To investigate the relation between the earnings quality on the cost of equity in the context of privatized firms, we estimate several specifications of the following model:

$$
R_{A V G_{i t}}=\delta_{0}+\delta_{1}\left|A A_{-} B A L L_{i t}\right|+\delta_{2} \text { CONTROLS }_{i t}+\gamma_{t}+\varepsilon_{i t}
$$

where CONTROLS represent our firm- and country-level control variables, $\gamma_{t}$ represent year and industry dummies controlling for year and industry fixed effects and $\varepsilon_{i t}$ is the error term.

Following the recent empirical literature on the cost of equity, we include in CONTROLS the following variables: First, we use the logarithm of the firm's total assets in US dollar as our proxy for the firm's size and we expect a negative association between the cost of equity and SIZE, in line with Fama and French (1992) and Hail and Leuz (2006). Second, we control for the number of years following the privatization year (TIME) to account for the effects of trends/years from privatization event. Third, we control for leverage using the ratio of the total book value of debt divided by the sum of market value of equity and the book value of debt (LEVERAGE). Since financial leverage increases the cost of equity (Modigliani and Miller, 1963), we expect a negative relation between $R_{A V G}$ and LEVERAGE. Fourth, we control for the market-to-book ratio (MARKET TO BOOK). Fama and French (1992) find that realized stock returns are positively related to the book-to-market ratio, implying a negative association between the market-to-book ratio and the implied cost of equity. Extensive empirical literature support these conjecture (e.g., Gebhardt et al., 2001; Gode and Mohanram, 2003; Hail and Leuz, 2006). Given that, we expect a negative association between $R_{A V G}$ and MARKET TO BOOK. Fifth, we use the firm's long-term growth rate by the five-year earnings growth rate $\left(G R O W T H_{-} R A T E\right)$ available in $\mathrm{I} / \mathrm{B} / \mathrm{E} / \mathrm{S}$ to control for long term growth rate. Prior literature (e.g., Gebhardt et al., 2001; Gode and Mohanram, 2003), among others) shows a positive association between the earnings growth rate and the implied cost of equity, suggesting that the market perceives high growth firms as riskier, consistent with the asset pricing theory. Accordingly, we expect a positive association between $R_{A V G}$ and GROWTH_RATE. Sixth, we control for the expected inflation rate (INFL), measuring it as the annualized yearly median of a country-specific, one-year-ahead realized monthly inflation rate. The introduction of INFL is motivated by the fact that analyst forecasts, stock prices, the book value of equity — the key inputs of the cost of equity —are all expressed in nominal terms and local currencies. Therefore, our estimates of the cost of equity reflect the country's expected inflation rate.

As outlined by Megginson and Netter (2001), empirical work on privatization may be weakened by the selection bias problem due to the fact that the government may divest the "healthiest" and the "easiest" firms first. Also, the government may be reluctant to relinquish control in some companies such as those belonging to strategic industries. Following prior literature (e.g., Villalonga, 2000; Boubakri et al., 2005), we address this issue using an industry fixed-effects model, in line with Boubakri, Cosset, and Guedhami (2005) and Ben-Nasr, Boubakri, and Cosset (2012).

Table 3 reports the results from estimating equation (6) for the five-year post-privatization window (i.e., from one year after privatization to five years afterward). In all models, we control for firm- and country-level determinants of the firm's cost of equity. We also control for the time trend using TIME. The results of Model (1), our basic regression, where we include $\left|A A_{-} B A L L\right|$ along with our control variables provide evidence that is consistent with 
our prediction: the cost of equity of privatized firms is negatively related to the quality of earnings. Specifically, we find that the coefficient of $\left|A A_{-} B A L L\right|$ is positive and statistically highly significant, suggesting that higher earnings quality is associated with high precise information about the cash flows of the firm, which reduces the amount of information risk (e.g., Lambert et al., 2008), leading to a lower cost of equity. It is also consistent with the conjecture that higher earnings quality is associated with lower information asymmetry and lower systematic risk, respectively. A lower information asymmetry and lower systematic risk are associated with lower cost of equity, respectively.

Models (2) and (3) extend our basic regression. In Model (2), we control for analyst coverage (ANALYST_COV). The forecast bias may reflect the firm's disclosure policies. For example, Hope (2003) documents significant cross-country differences in forecast accuracy and reports a significant association between forecasted accuracy and the firm's annual reported disclosure. The forecast bias may also reflect earnings surprises. For example, Gebhardt et al. (2001) argue that the forecast bias reflects unpredictable earnings forecasts. Mikhail et al. (2004) find that firms with repeated earnings surprises experience a higher cost of equity. The results show that the coefficient for $\left|A A_{-} B A L L\right|$ is still positive and statistically highly significant, corroborating our earlier finding. In Model (3), we control for legal investor protection using the anti-self-dealing index (ANTISELF) from Djankov, La Porta, Lopez-de-silianes and Shleifer, 2008. Prior litearture (e.g., Hail and Leuz, 2006; Chen et al., 2009) show legal investor protection affects the cost of equity capital. Specifically, they show that sound legal institutions are associated with lower agency risk, hence with lower equity financing costs. Consistent with this point of view, the results of Model (3) show a negative and highly significant coefficient for ANTISELF. More importantly for our purposes, the coefficient for $\left|A A_{-} B A L L\right|$ remains negative and highly significant, again supporting our earlier finding.

We estimate significant relations between our firm-level and country-level control variables and the cost of equity, respectively. We find that the coefficient of our proxy for firm size is negative and significant at the $1 \%$ level across all models, consistent with the findings of Fama and French (1992) and Gebhardt et al. (2001). We also find that TIME is negative and significant at the $1 \%$ level across all models, in line with Ben-Nasr et al. (2012). Additionally, we find that the coefficient for MARKET TO BOOK is negative and significant at the $1 \%$ level across all specifications, consistent with the findings of Fama and French (1992), Gode and Mohanram (2003), and Hail and Leuz (2006), among others. Furthermore, we find a positive and highly significant for GROWTH_RATE across all models, in line with the findings of the literature on the implied cost of equity (e.g., Gode and Mohanram (2003)). Finally, we find that the coefficient for INFL is positive and significant at the $1 \%$ level across all models, consistent with prior litearature (e.g., Hail and Leuz, 2006; Ben-Nasr et al., 2012).

Table 3. Earnings quality and the cost of equity




ANALYST COV

ANTISELF

Intercept

INDUSTRY EFFECTS

YEAR EFFECTS

$\mathrm{N}$

Adj R2
$?$

0.194

$(6.135)^{* * *}$

YES

YES

307

0.199
0.000

$(0.200)$

$\begin{array}{ll} & -0.036 \\ & (-2.276)^{* *} \\ 0.195 & 0.227 \\ (6.211)^{* * *} & (5.532)^{* * *} \\ \text { YES } & \text { YES } \\ \text { YES } & \text { YES } \\ 307 & 307 \\ 0.199 & 0.219\end{array}$

This table presents fixed effects estimation results from regressing the average of implied cost of equity estimates on earnings quality and control variables. The full sample includes 161 privatized firms from 32 countries between 1987 and 2006. The results are reported for a period of five years i.e., from one year after privatization to five years after privatization. Beneath each estimate is reported the $z$-statistic. The superscripts asterisks $* * *$, **, and * denote statistical significance at the $1 \%, 5 \%$, and $10 \%$ levels, respectively, one-tailed when directional predictions are made, and two-tailed otherwise. $R_{A V G}$ is the average cost of equity estimated using the four models described in the in section (B) Implied cost of equity models. Descriptions and data sources for the variables are outlined in Appendix A.

\section{Conclusion}

Our paper contributes to the literature on stock price earnings quality and the cost of equity capital by employing the privatization framework as a testing laboratory. Specifically, using a multinational sample of 161 newly privatized firms from 32 countries, we examine the impact of discretionary abnormal accruals on the cost of equity. We find strong and robust evidence that lower absolute value of discretionary abnormal accruals (i.e., higher earnings quality) is associated with lower cost of equity, suggesting that higher earnings quality is associated with high precise information about the cash flows of the firm, which reduces the amount of information risk (e.g., Lambert et al., 2008), leading to a lower cost of equity. Our finding is also consistent with the conjecture that higher earnings quality is associated with a lower cost of equity capital since it is accompanied with lower information asymmetry and lower systematic risk, respectively.

Our finding outlines the importance of improving earning quality of privatized firms. Indeed, it suggests that less transparent information environment, leads to a higher cost of equity financing, which may adversely affect the survival of the privatized firms (and hence the success of the privatization process). Economic growth is also at stake, since a higher cost of equity financing disables privatized firms to carry forward value-enhancing and positive net-present-value projects, which may impede economic growth.

\section{Acknowledgement}

We would like to thank the Deanship of Scientific Research at King Saud University, represented by the research center at CBA, for supporting this research financially.

\section{References}

Ball, R., \& Shivakumar, L. (2005). Earnings quality in UK private firms: Comparative loss recognition. Journal of Accounting and Economics, 38, 83-128. http://dx.doi.org/10.1016/j.jacceco.2004.04.001

Barth, M.E., Konchitchki, Y., \& Landsman, W.R. (2013). Cost of capital and earnings transparency. Journal of Accounting and Economics, 55, 206-224. http://dx.doi.org/10.1016/j.jacceco.2013.01.004

Ben-Nasr, H., Boubakri, N., \& Cosset, J.C. (2012). The political determinants of the cost of equity: Evidence from newly privatized firms. Journal of Accounting Research, 50, 605-646. http://dx.doi.org/10.1111/j.1475-679X.2011.00435.x

Ben-Nasr, H., Boubakri, N., \& Cosset, J.C. (2014). Earnings quality in privatized firms: The role of state and foreign owners. Journal of Accounting and Public Policy, Forthcoming. Retrieved from 
https://www.researchgate.net/publication/261288556_Earnings_Quality_in_Privatized_Firms_The_Role_of_Sta te_and_Foreign_Owners

Bhattacharya, N., Desai, H., \& Venkataraman, K. (2013). Does earnings quality affect information asymmetry? Evidence from trading costs. Contemporary Accounting Research, 30, 482-516. http://dx.doi.org/10.1111/j.1911-3846.2012.01161.x

Bhattacharya, N., Ecker, F., Olsson, P.M., \& Schipper, K. (2012). Direct and mediated associations among earnings quality, information asymmetry, and the cost of equity. The Accounting Review, 87, 449-482. http://dx.doi.org/10.2308/accr-10200

Bhattacharya, U., Daouk, H., \& Welker, M. (2003). The world price of earnings opacity. The Accounting Review, 78, 641-678.

Bortolotti, B., \& Faccio, M. (2009). Government control of privatized firms. Review of Financial Studies, 22, 2907-2939. http://dx.doi.org/10.1093/rfs/hhn077

Boubakri, N., Cosset, J.C., \& Guedhami, O. (2005). Post-privatization corporate governance: The role of ownership structure and investor protection. Journal of Financial Economics, 76, 369-399. http://dx.doi.org/10.1016/j.jfineco.2004.05.003

Boubakri, N., Cosset, J.C., Guedhami, O., \& Saffar, W. (2011). The political economy of residual state ownership in privatized firms: Evidence from emerging markets. Journal of Corporate Finance, 17, 244-258. http://dx.doi.org/10.1016/j.jcorpfin.2010.08.003

Brushwood, J.D., Dhaliwal, D.S., Fairhurst, D.J., \& Serfling, M.A. (2014). Property theft and the cost of equity capital. Working Paper, The University of Arizona. Retrieved from http://aaahq.org/AM2014/display.cfm?Filename=SubID_1860.pdf\&MIMEType=application\%2Fpdf

Chahrumilind, C., Kall, R., \& Wiwattanakantang, Y. (2006). Connected lendings: Thailand before the financial crisis. Journal of Business, 79, 181-218.

Chaney, P.K., Faccio, M., \& Parsley, D. (2011). The quality of accounting information in politically connected firms. Journal of Accounting and Economics, 51, 58-76. http://dx.doi.org/10.1016/j.jacceco.2010.07.003

Chen, K.C.W., Chen, Z.H., \& Wei, K.C.J. (2009). Legal protection of investors, corporate governance, and the cost of equity capital. Journal of Corporate Finance, 15, 273-289. http://dx.doi.org/10.1016/j.jcorpfin.2009.01.001

Claus, J.J., \& Thomas, J.K. (2001). Equity premia as low as three percent? Evidence from analysts' earnings forecasts for domestic and international stock markets. Journal of Finance, 56, 1629-1666. http://dx.doi.org/10.1111/0022-1082.00384

Dechow, P.M., \& Dichev, L. (2002). The quality of accruals and earnings: The role of accrual estimation errors. The Accounting Review, 77, 35-59.

Degeorge, F., Ding, Y., Jeanjean, T., \& Stolowy, H. (2013). Analyst coverage, earnings management and financial development: An international study. Journal of Accounting and Public Policy, 32, 1-25. http://dx.doi.org/10.1016/j.jaccpubpol.2012.10.003

Denis, D. K., \& McConnell, J.J. (2003). International corporate governance. Journal of Financial and Quantitative Analysis, 38, 1-36.

Dhaliwal, D., \& Heitzman, S., Li, O.Z. (2006). Taxes, leverage, and the cost of equity capital. Journal of Accounting Research, 44, 691-723. http://dx.doi.org/10.1111/j.1475-679X.2006.00214.x

Dhaliwal, D., Judd, J.S., Serfling, M., \& Shaikh, S. (2014). Customer concentration and the cost of equity capital. Working Paper, The University of Arizona. Retrieved from http://aaahq.org/AM2014/display.cfm?Filename=SubID_1864.pdf\&MIMEType=application\%2Fpdf

Diamond, D., \& Verrecchia, R. (1991). Disclosure, liquidity, and the cost of capital. Journal of Finance, 46, 1325-1359. http://dx.doi.org/10.1111/j.1540-6261.1991.tb04620.x

Djankov, S., La Porta, R., Lopez-de-Silanes, F., \& Shleifer, A. (2008). The law and economics of self-dealing. Journal of Financial Economics, 88, 403-465. http://dx.doi.org/10.1016/j.jfineco.2007.02.007

Dyck, A. (2001). Privatization and corporate governance: Principles, evidence, and future challenges. World Bank Research Observer, 16, 59-84. 
Easley, D., Hvidkjær, S., \& O’Hara, M. (2002). Is information risk a determinant of asset returns? Journal of Finance, 57, 2185-2221. http://dx.doi.org/10.1111/1540-6261.00493

Easton, P. (2004). PE ratios, PEG ratios, and estimating the implied expected rate of return on equity capital. The Accounting Review, 79, 73-96.

Faccio, M., McConnell, J.J., \& Masulis, R. W. (2006). Political connections and corporate bailouts. Journal of Finance, 61, 2597-2635. http://dx.doi.org/10.1111/j.1540-6261.2006.01000.x

Fama, E., \& French, K. (1992). The cross sections of expected stock returns. Journal of Finance, 47, $427-466$. http://dx.doi.org/10.1111/j.1540-6261.1992.tb04398.x

Francis, J., LaFond, R., Olsson, P., \& Schipper, K. (2004). Costs of equity and earnings attributes. The Accounting Review, 79, 967-1010.

Francis, J., LaFond, R., Olsson P., \& Schipper, K. (2005). The market pricing of accruals quality. Journal of Accounting and Economics, 39, 295-327. http://dx.doi.org/10.1016/j.jacceco.2004.06.003

Gebhardt, W.R., Lee, C.M.C., \& Swaminathan, B. (2001). Toward an Implied Cost of Capital. Journal of Accounting Research, 39, 135-176. http://dx.doi.org/10.1111/1475-679X.00007

Gode, D., \& Mohanram, P. (2003). Inferring the cost of capital using the Ohlson-Juettner model. Review of Accounting studies, 8, 399-431. http://dx.doi.org/10.1023/A:1027378728141

Hail, L., \& Leuz, C. (2006). International differences in cost of equity capital: Do legal institutions and securities regulations matter? Journal of Accounting Research, 44, 485-531. http://dx.doi.org/10.1111/j.1475-679X.2006.00209.x

Hail, L., \& Leuz, C. (2009). Cost of capital effects and changes in growth expectations around U.S. cross listings. Journal of Financial Economics, 93, 428-454. http://dx.doi.org/10.1016/j.jfineco.2008.09.006

Hope, O. (2003). Disclosure practices, enforcement of accounting standards and analysts' forecast accuracy: An international study. Journal of Accounting Research, 41, 235-73. http://dx.doi.org/10.1111/1475-679X.00103

Hwang, L.S., Lee, W.J., Lim, S.Y., \& Park, K.H. (2013). Does information risk affect the implied cost of equity capital? An analysis of PIN and adjusted PIN. Journal of Accounting and Economics, 55, 148-167. http://dx.doi.org/10.1016/j.jacceco.2013.01.005

Lambert, R., Leuz, C., \& Verrecchia, R. (2008). Information asymmetry, information precision, and the cost of capital. Working Paper, University of Pennsylvania and University of Chicago

Megginson, W. (2003). Appendix 1: Details of share issue privatizations, 1961-2003. In Megginson, W.L. (Ed.), Financial Economics of Privatization. New York: Oxford University Press.

Megginson, W., \& Netter, N.J. (2001). From state to market: A survey of empirical studies on privatization. Journal of Economic Literature, 39, 321-389.

Mikhail, M., Walther, B., R., \& Willis, R. (2004). Earnings surprises and the cost of equity capital. Journal of Accounting Auditing and Finance, 9, 491-514. http://dx.doi.org/10.1177/0148558X0401900409

Mishra, F. (2014). The dark side of CEO ability: CEO general managerial skills and cost of equity capital. The Journal of Corporate Finance, 29, 390-409. http://dx.doi.org/10.1016/j.jcorpfin.2014.10.003

Modigiliani, F., \& Miller, M. (1963). Corporate income taxes and the cost of capital: A correction. American Economic Review, 53, 433-443.

Ohlson, J., \& Juettner-Nauroth, B. (2005). Expected EPS and EPS growth as determinants of value. Review of Accounting Studies, 10, 349-65.

Villalonga, B. (2000). Privatization and efficiency: Differentiating ownership effects from political, organizational, and dynamic effects. Journal of Economic Behavior and Organization, 42, 43-74. 


\section{APPENDIX}

Variables, Descriptions, and Sources

\begin{tabular}{|c|c|c|}
\hline Variable & Description & Source \\
\hline$\overline{R_{A V G_{i t}}}$ & \multicolumn{2}{|c|}{$\begin{array}{l}\text { Dependent variable, our estimate of the cost of equity, which is the average of Authors' } \\
R_{O J}, R_{C T}, R_{G L S} \text {, and } R_{E S} . R_{O J} \text { is the implied cost of equity estimated from the estimation } \\
\text { Ohlson and Juettner-Nauroth (2005) model. } R_{C T} \text { is the implied cost of equity } \\
\text { estimated using the Claus and Thomas (2001) model. } R_{G L S} \text { is the implied cost of } \\
\text { equity estimnated using the Gebhardt, Lee and Swaminathan (2001) model. } R_{E S} \\
\text { is the implied cost of equity estimated using the Easton (2004) model. The four } \\
\text { models are described in } \\
\text { section (B) Implied cost of equity models. }\end{array}$} \\
\hline$\left|A A_{-} B A L L\right|$ & \multicolumn{2}{|c|}{$\begin{array}{l}\text { Absolute value of abnormal accruals estimated using Ball et al.'s (2005) model Authors' } \\
\text { outlined in section (A) abnormal Accruals. }\end{array}$} \\
\hline SIZE & The logarithm of the firm's total assets in US dollar. & Worldscope \\
\hline$T I M E$ & The number of years since the privatization year & $\begin{array}{l}\text { Authors' } \\
\text { calculation }\end{array}$ \\
\hline LEVERAGE & $\begin{array}{l}\text { Total book value of debt divided by the sum of market value of equity and the } \\
\text { book value of debt. }\end{array}$ & Worldscope \\
\hline MARKET TO BOOK & The market-to-book ratio. & Worldscope \\
\hline GROWTH_RATE & $\begin{array}{l}\text { Five year growth rate from } \mathrm{I} / \mathrm{B} / \mathrm{E} / \mathrm{S} \text {. If this rate isn't available in } \mathrm{I} / \mathrm{B} / \mathrm{E} / \mathrm{S} \text { II } \\
\text { estimate it using forecasted second and third years earnings per share. }\end{array}$ & I I/B/E/S \\
\hline$I N F L$ & $\begin{array}{l}\text { The annualized yearly median of a country specific one-year-ahead realised I } \\
\text { monthly inflation rate. }\end{array}$ & Datastream \\
\hline ANALYST_COV & $\begin{array}{l}\text { The number of analysts who provided estimates of the forecasted earnings per I } \\
\text { share reported in } \mathrm{I} / \mathrm{B} / \mathrm{E} / \mathrm{S} \text {. }\end{array}$ & $\mathrm{I} / \mathrm{B} / \mathrm{E} / \mathrm{S}$ \\
\hline ANTISELF & Average of ex-ante and ex-post private control of self-dealing. & $\begin{array}{l}\text { Djankov et al. } \\
(2008)\end{array}$ \\
\hline
\end{tabular}

